\title{
Kobi’lerin Finansal Sorunlarının İncelenmesinde Dış Kaynağın Rolü: Diyarbakır İli Örneği
}

\section{The Role of External Source in the Examination of the Financial Problems of SMEs: Example of Diyarbaktr}

\author{
Özcan Demir a , Delal Aydın ${ }^{\text {b }}$, Eray Ekin Sezgin c,* \\ ${ }^{a}$ Dr. Öğr. Üyesi, Fırat Üniversitesi, İ̈BF Fakültesi, İşletme Bölümü, Elazı̆̆/Türkiye. \\ ORCID: 0000-0001-9382-6781 \\ b Yüksek Lisans Öğrencisi, Fırat Üniversitesi, İİBF Fakültesi, İşletme Bölümü, Elazı̆̆/Türkiye. \\ ORCID: 0000-0002-1135-5128 \\ ${ }^{c}$ Dr. Fırat Üniversitesi, İ̈BF Fakültesi, Sağlık Yönetimi Bölümü, Elazığ/Türkiye \\ ORCID: 0000-0002-8565-0269
}

\section{MAKALE BILGİSI}

\section{Makale Geçmişi:}

Başvuru tarihi: 15 Ağustos 2018

Düzeltme tarihi: 07 Eylül 2018

Kabul tarihi: 05 Kasim 2018

\section{Anahtar Kelimeler:}

KOBI

Finansman Sorunları

Dış Kaynak

\section{ARTICLE INFO}

\section{Article history:}

Received 15 August 2018

Received in revised form 07 September 2018

Accepted 05 November 2018

\section{Keywords:}

SMEs

Financial Problems

External Source
ÖZ

Çalışmamızda, Diyarbakır ilinde faaliyet gösteren 386 adet KOBI üzerinde dış kaynaktan temin edilen krediler ve bunların işletmede yarattı̆̆ 1 sorunlar ortaya konulmaya çalışılmıştır. Yapılan çalışmanın sonuçlarını şu çerçevede özetleyebiliriz. İşletmelerin büyük bir bölümünün kredilerle finansman sağladıkları ve bu kredilerin büyük bir kısmını bankalardan temin ettikleri görülmüştür. $\mathrm{Bu}$ bağlamda işletmelerin KOSGEB'in kredilerinden yeterince yararlanmadıkları tespiti yapılmış, bunun nedeninin de kamu borcu olan işletmelerin aldığı krediden borcu kadar kesinti yapılmasıdır. Kredi kullanan işletmeler, kredi kullanımında yaşadığı zorlukların önemli bir bölümünü teminat sağlama ve formalite- şekil şartları olarak ifade etmişlerdir. Bununla birlikte işletmelerin önemli bir kısmı kredinin miktarı bakımından bir sorun ortaya koyamamaktadır. Çalışmamızdaki veriler, istatistiksel bir ortamda değerlendirilmiş ve kurulan hipotezlerin test edilmesi bu çerçevede gerçekleştirilmiştir.

\section{A B S T R ACT}

In our study on 386 SMEs operating in Diyarbakir province, external source loans and the problems posed by these companies are tried to be put forward. We can summarize the results of the study in this frame. It was observed that most of the enterprises provided financing by loans and obtained a large portion of these loans from banks. In this regard, it is determined that the enterprises did not benefit enough from KOSGEB loans and the reason for this is the deduction made by the government borrowing enterprises as much as the debt received from the creditors. The enterprises that use credit have stated a significant portion of the difficulties which experienced in the use of credit as providing collateral and formality-form conditions. At the same time, a significant portion of the enterprises cannot present a problem in terms of the amount of the loan. The data in our study have been evaluated in a statistical environment and testing of the hypotheses established was carried out in this framework.

\section{Giriş}

Küçük ve Orta Büyüklükteki İşletmelerin (KOBI'lerin), istihdama, yatırımlara, üretime, ürün çeşitliliği yaratarak talep değişikliklerine uyum sağlayabilmeleri, düşük yatırım maliyetleriyle istihdama katkı sağlamaları, kişisel tasarrufları teşvik etmeleri, büyük işletmelerin yan sanayi olarak tamamlayıcısı olmaları ve ekonomik değişikliklerden daha az etkilenmeleri nedenleriyle ülke ekonomilerinde oldukça önemli bir yer tuttuğu aşikârdır. KOBI'lerin ülke ekonomilerine sağladığı katkılara karşın gerek kendi iç yapılarından gerekse de ekonomik ortamdan kaynaklanan bazı sorunların olduğu bir gerçektir. Bu sorunlar, işletmenin her alanında ortaya çıkabilmektedir.

Finansman, KOBI'lerin karşılaştı̆̆ biridir. KOBI'lerin bütün sorunlarının temelinde finansal sorunlar özellikle de dış kaynaklı sorunlar yatmaktadır. Dış

* Sorumlu yazar/Corresponding author.

e-posta: eray_ekin_1907@hotmail.com 
kaynaktan borçlanılan finansman güçlüğü KOBI'ler için çoğu kez daha kuruluş aşamasında başlamakta ve yaşamları boyunca da faaliyetlerini ve gelişmelerini olumsuz yönde etkilemektedir. Ülke ekonomilerinin vazgeçilmez yapıtaşlarından biri olan KOBI'leri zayıflatan finansal sorunların özellikle de dış kaynağın aşılması bu nedenle daha da önem kazanmaktadır. Ekonomik, sosyal ve toplumsal açıdan önemleri dikkate alınarak KOBI'lerin bu sorunu aşabilmeleri için desteklenip teşvik edilmeleri gerekmektedir. Ancak doğru destek ve teşviklerin yapılabilmesi için sorunun kaynağının doğru belirlenmesi önem taşımaktadır.

$\mathrm{Bu}$ çalışmanın amacı Diyarbakır ilinde faaliyet gösteren küçük ve orta büyüklükteki işletmelerin finansman ile ilgili sorunlarını ortaya çıkarmak, bu sorunların irdelenmesinde dış kaynağın etkin rolünü ortaya koyarak çözüm önerileri geliştirmektir.

\section{KOBI: Kavramsal Çerçeve}

Ekonomik ve sosyal sistemi, esnek, dinamik ve değişebilen yapılarıyla olumlu yönde etkileyen KOBI'ler için birçok farklı tanım yapılabilmektedir. KOBI tanımlarında akademisyenler, ilgili kuruluşlar ve ilgili kanunlar arasında herhangi bir fikir birliği oluşmamıştır. KOBI kavramının genel kabul görmüş bir tanımının yapılamamış olması, küçük ve orta büyüklükteki işletmelerin geniş bir alanı kapsamasının yanında ölçekle ilgili kriterlerin göreceli bir özellik taşımasından da kaynaklanmaktadır. Yani büyüklük ölçüsü olarak hangi kriterlerin alınacağı ve bunların miktarı konusunda ülkemizde çeşitli görüşler bulunmaktadır (Düşükcan ve Sezgin, 2017: 155-156).

Resmi Gazete'nin 24 Haziran 2018 tarihli sayısında Bakanlar Kurulu'nca yayımlanan 2018/11828 sayılı BKK ile "Küçük ve Orta Büyüklükteki İşletmelerin Tanımı, Nitelikleri ve Sınıflandırılması Hakkında Yönetmelikte Değişiklik Yapılmasına Dair Yönetmelik” ile KOBI tanımı yeniden belirlendi. KOBI'nin tanımı yeni yapılan yönetmeliğe göre "Yıllık net satış hâsılatı" ve "Mali bilanço" üst limiti 25 milyon TL'den 40 milyon TL'ye yükseltilirken, yıllık çalışan personel sayısı üst limiti 250 çalışan olarak korundu. Yapılan düzenleme ile mikro, küçük ve orta büyüklükteki ekonomik birim ve girişimlerin tanımları yeniden belirlendi. Bu bağlamda (TOBB, 2012);

(i) Mikro İşletmeler: 10 kişiden az yıllık çalışan istihdam eden ve yıllık net satış hâsılatı veya mali bilançodan herhangi biri 1 milyon TL aşmayan işletmeler, mikro işletme olarak adlandırılmaktadır. Mikro işletme tanımında değişiklik yapılmamıştır.

(ii) Küçük İşletmeler: 50 kişiden az yıllık çalışan istihdam eden ve yıllık satış hâsılatı veya mali bilançosundan herhangi biri 8 milyon Türk Lirasını aşmayan işletmeler küçük işletme olarak adlandırılmaktadır. Daha önceden 5 milyon TL olan satış hâsılatı veya mali bilanço üst limiti 8 Milyon TL'ye yükseltilmiştir.

(iii) Orta Büyüklükteki İşletmeler: 250 çalışandan az istihdam rakamı ve yıllık satış hasılatı veya mali bilançosundan herhangi biri 40 milyon TL'yi aşmayan işletmeler, orta büyüklükte işletme olarak adlandırılmaktadır. Daha önceden 25 milyon TL olan satıș hâsılatı veya mali bilanço üst limiti 40 milyon TL'ye yükseltilmiştir.

KOBI'ler doğru politikalarla desteklendiğinde, bu durum ülke ekonomileri açısından olumlu sonuçlar doğurabilir. Zira KOBI'ler sağlam bir ekonomik sistemin temellerini oluşturabilirler ve ekonomik büyümeyi uyarıcı rol oynayabilirler; girişimciliği teşvik ederler; genellikle emek yoğun üretim modelleri kullandıklarından istihdam doğururlar; kısa sürede kurulup üretime başlayabilirler; bölgeler arasındaki gelişmişlik farkının kalkmasına yardımcı olurlar ve büyük işletmelerin ekonomideki gücünü dengeleyebilirler (Cook ve Nixon, 2001: 1).

\subsection{KOBI'lerin Avantaj ve Dezavantajları}

İçinde bulunduğumuz 21'inci yüzyılda hız kazanan ve birbirini etkileyen teknolojik, ekonomik ve sosyal gelişmeler büyük ölçekli işletmelere oranla KOBI'leri önemli ölçüde etkilemiştir (Vural, 2007:8). Nitelikli işgücüne sahip, ihtisaslaşmış, bilgi paylaşımını üst seviyeye çıkarmış ve aynı zamanda inovasyona açık firmalar yeni küresel güç haline gelmiştir. KOBI'ler küresel güç olma yolunda ilerleyip değişmektedir ve bu değişim beraberinde bazı avantaj ve dezavantajları getirmektedir (Gedik, 2011: 15).

\subsubsection{KOBI'lerin Avantajlarl}

Küçük bir işletmeye sahip olma, öncelikle büyük işletmelerle, rekabet konusunda işletme sahibine belirli avantajlar sağlayabilmektedir. Bu yüzden KOBI'ler;

(i) Büyük miktarda yatırıma girmeden önce yeni bir fikir veya buluşa pazarın tepkisinin bilinmesinin zorunlu olmasinda,

(ii) Yönetimde çok yakın denetime ihtiyaç hissedilmesinde,

(iii) Üretilen mal ve hizmetin pazarının sınırlı olmasında,

(iv) El emeğinin mal ve hizmetin üretilmesinde önemli bir faktör olarak yer almasında,

(v) Üretilen mal veya hizmete olan talebin sinırlı olmasinda,

(vi) Kolay bozulabilen malların pazarlanması ya da üretilmesinde,

(vii) Personel ile yakın ilişkilerin gerekli olmasında,

(viii) Teknik gelişmelere kısa sürede ayak uydurabilme yeteneğine sahip olunmasında,

(ix) Yatırım yapılırken daha çok kendi öz sermayelerine ağırlık verilmesinde,

(x) Desteklenmeleri aynı zamanda ülkedeki işsizliğin azalması anlamına gelmesinde,

(xi) İşgörenlerin kendi bölgeleri veya yasamak istedikleri bölgelerde kurulmasında,

(xii) Ülke içindeki farklı bölgelerin kalkınmasında ve çevrenin korunmasında bir takım avantajlar elde edebilmektedir (Akgemici, 2001: 15-16).

\subsubsection{KOBI'lerin Dezavantajlart}

KOBI'ler aşağıda yer alan bazı dezavantajlara sahiptir.

(i) Satışlarda meydana gelen dalgalanmalar: Satışlardaki dengesizlikler sebebiyle KOBI sahipleri nakit sıkışıklığı yaşamakta bunu telafi için kısa dönemli borçlanmalara girebilmektedirler.

(ii) Mali kayıplar: KOBI'ler de kararların sahipleri tarafından alınması yanlış kararlar alındığında 
bunların telafisi çok zor olmakta ve bazı hallerde de KOBI patronlarını iflasın eşiğine getirebilmektedir.

(iii) Çalıştırılan elemanla ilişkiler: Doğru eleman seçiminde bulunmak ve doğru bir insan kaynakları yönetimi yapmak stratejik önem taşır. Bu durum işin doğasına, müdürlerin beceri ve hayal gücüne; liderlerin kişisel seçimlerine bağlı olarak ve şirketten şirkete değişir (Burlingham, 2007: 146).

(iv) Başarısızlık riski: KOBI sahipleri, yerine getirmeleri gereken yükümlülükleri yapmamaktadırlar. $\mathrm{Bu}$ durum ise işyerlerini iflasa kadar götürmektedir. (Sariaslan, 1999: 25).

\subsection{KOBI'lerin Finansman Kaynakları ve Dış} Kaynak İle İlişkisi

KOBI'ler küçük ve ilk kurulduklarında yeterli miktarda sermaye sahibi olmayan kuruluşlar olduğu için çeşitli kaynaklardan finansman yardımı alırlar. Aldıkları fon ve finansman yardımlarını, girişimcilikleri ve pazar hedefleriyle birleştirdikleri takdirde yeterli bir büyüme gösterirler. KOBI'lerin kullandığı bu finansman kaynaklarını şu şekilde sıralayabiliriz; Risk sermayesi, KOSGEB, banklar, leasing, factoring, mikro finansman, forfaiting, barter.

$\mathrm{Bu}$ büyümenin sonrasında kendilerine finansman kaynağ sağlayan kuruluşlara elde edilen kazanç üzerinden daha önceden belirlenen oran üzerinden hisse verilir. Bu şekilde her iki kuruluşunda karşılıklı çıkarları gözetilerek, kazançlı ve sağlam bir büyümenin temellerini atmış olur.

Tablo 1. Kullanılan Finans Kaynaklarına Göre İşletmelerin Dağılımı (\%)

\begin{tabular}{|c|c|c|c|c|}
\hline $\begin{array}{l}\text { Finansman } \\
\text { Kaynakları }\end{array}$ & $\begin{array}{c}\text { Küçük } \\
\text { Ölçekli } \\
\text { İşletmeler }\end{array}$ & $\begin{array}{c}\text { Orta } \\
\text { Ölçekli } \\
\text { İşletmeler }\end{array}$ & $\begin{array}{c}\text { Büyük } \\
\text { Ölçekli } \\
\text { İşletmeler }\end{array}$ & $\begin{array}{l}\text { Toplam } \\
\text { İşletmeler }\end{array}$ \\
\hline $\begin{array}{l}\text { Ticari } \\
\text { Bankalar }\end{array}$ & 70,4 & 76,7 & 80,2 & 74,6 \\
\hline Özkaynak & 66,9 & 65,2 & 69,2 & 66,9 \\
\hline Eximbank & 8,5 & 24,8 & 40,5 & 20,6 \\
\hline Leasing & 14,1 & 20,0 & 25,2 & 18,4 \\
\hline Factoring & 10,2 & 7,6 & 19,1 & 11,2 \\
\hline $\begin{array}{l}\text { Yatırım ve } \\
\text { Kalkınma } \\
\text { Bankaları }\end{array}$ & 6,3 & 11,9 & 12,2 & 9,4 \\
\hline $\begin{array}{l}\text { Yurtdış1 } \\
\text { Finans } \\
\text { Kuruluşları }\end{array}$ & 0,4 & 1,9 & 14,5 & 3,8 \\
\hline Diğer & 2,8 & 2,4 & 3,8 & 2,9 \\
\hline
\end{tabular}

\begin{tabular}{lcccc}
\hline Diğer & 2,8 & 2,4 & 3,8 & 2,9 \\
\hline $\begin{array}{l}\text { Sermaye } \\
\text { Piyasası }\end{array}$ & & & & \\
$\begin{array}{l}\text { Araçları \& } \\
\text { Yatırım }\end{array}$ & 0,4 & 1,0 & 3,1 & 1,1 \\
Fonları & & & & \\
\hline Kanl & & & &
\end{tabular}

Kaynak: İSO (2013)

Tablo 1'de görüldüğü gibi işletmelerin büyüklüğü ne olursa olsun ticari banka kredileri işletme sermayesi olarak ilk sırayı almaktadır. Hemen arkasındansa özkaynak kullanım oranı gelmektedir. Eximbank, leasing, factoring, yatırım ve kalkınma bankaları, yurtdışı finans kuruluşları ve sermaye piyasası araçlarıysa kullanılan finans kaynakları içerisinde daha küçük paya sahiplerdir.

Türkiye'de KOBI'lerin rekabetçi yapıda olmalarını sağlamak amaçlandığı için, KOBI'lere yönelik sağlanan finansman kaynakları da bu yönde oluşturulmaktadır. KOBI'lere bu anlamda finansman sağlarken dikkat edilmesi gereken belli konular aşağıda belirtilmiştir (Taşçı, 2017: 3132):

(i) KOBI'lerle ilgili genel bir tanım yapılmalı ve ülke genelinde bu tanımın esas alınması sağlanarak bu şekilde finansman kaynakları sağlanmalıdır.

(ii) KOBI'lere yönelik ayrılan destek ve fonların gerçekten ihtiyacın olduğu alanlarda ve işletmelerde kullanılması sağlanmalıdır.

(iii) KOBI'lerin banka kredilerine ulaşımını zorlaştıran ipotek, teminat gibi kısitlayıc1 etkenlerin etkilerini daha az etkili hale getirmek amaciyla kurumsal bir yapının oluşması sağlanmalıdır.

(iv) Dünyada uygulanan KOBI finansman araçlarının Türkiye'de de uygulanmasını sağlamak amacıyla gerekli alt yapının oluşturulması, bu yöntemlerin tanıtılması ve uygulamaya geçişi sağlanmalıdır.

(v) KOBI'lere sermaye piyasası üzerinden fon sağlamak için KOBI'lere menkul kıymetler borsası kurulmalıdır.

(vi) KOBI'lerin rekabetçi yapılarındaki farklı özellikler göz önüne alınarak onlara ürün ve hizmet anlamında destek sağlanmalıdır.

Dış Kaynak (Yabancı Kaynak), KOBI'lerin borçlanma yoluyla sağladığı kaynaklardır. İşletmelerin diş kaynaklardan sağladıkları bu fonlara yabancı sermaye de denir. Yabancı kaynaklar, yalnızca para olarak değil, maddesel değerler de olabilir (finansal kiralama yoluyla elde edilen maddi varlıklar gibi).

Dış Kaynak, kullanım süresi bakımından; Kısa süreli yabancı kaynaklar (kısa süreli borçlar) ve uzun süreli yabancı kaynaklar (uzun süreli borçlar) olarak ikiye ayrılır (Sarialtın, 2011).

Kısa Süreli Yabancı Kaynaklar: Muhasebe ve finansal dilde "cari pasifler" olarak adlandırılan kısa süreli borçlar, geri ödeme süresi bir yıla kadar olan borçlardır. Kısa süreli, borçlar, bir yıl veya daha az süreli olarak çalışma sermayesinin finansmanında kullanılırlar. İşletmelerin genellikle kısa vadeli finansmanda kullandıkları yabancı kaynaklar;

(i) Ticari krediler,

(ii) Ticari banka kredileri,

(iii) Finansman bonoları,

(iv) Faktöring,

(v) Ödenmesi gereken vergi, resim, harçlar; ücretler, ikramiyeler,

(vi) Alınan teminat, depozit ve avanslar ve tahakkuk etmiş giderler gibi kendiliğinden oluşan fonlardır.

Orta ve Uzun Süreli Yabancı Kaynaklar: Geri ödeme süresi $2,5,10,15$ ve 20 yıl gibi ödeme süreleri olan yabancı kaynaklar, genellikle duran varlıkların ya da devamlılık arz eden faaliyetlerin finansmanında kullanılır. Orta ve uzun süreli yabancı kaynaklar arasında;

(i) Orta/uzun vadeli banka kredileri,

(ii) Tahvil ihracı,

(iii) Finansal kiralama (leasing),

(iv) Forfaiting sayılabilir. 


\subsection{KOBI'lerin Finansman Sorunları}

Türkiye'de yapılan uygulamalı araştırmalarda KOBI'lerin karşılaştıkları sorunların başında finansman sorununun geldiği görülmektedir. Bununla birlikte gerek gelişmiş gerekse gelişmekte olan ülkelerde finansal kaynaklara ulaşmada yaşanan zorluklar da önemli bir problemdir (Green, 2003: 8). KOBI'lerin özellikle son yıllarda değişen pazar talepleri ile birlikte teknolojideki değişmelere uyumda kendi iç finansmanlarının yetersiz kalması, mevcut kapasitelerini arttırması ve modernizasyon için gerekli atılımlarda bulunması da önemli bir sorun olarak karşımıza çıkmaktadır (Çelik ve Akgemci, 1998: 5). Bu sorunun temelinde ise KOBI'lerin özsermaye yapıları yatmaktadır. $\mathrm{Bu}$ sorun günümüzde halen devam etmekle birlikte işletmelerin geleceğini de olumsuz etkilemektedir. Finansman sorunu aynı zamanda tedarik, üretim, pazarlama ve eğitim gibi diğer önemli bazı sorunları da beraberinde getirmektedir.

Türkiye'de küçük ve orta büyüklükteki işletmelerin sorunları konusunda yapılan uygulamalı çalışmalarda, finansman sorunu genel olarak sorunlar listesinin ilk siralarında yer almaktadır. Bu durumun sebebi Türkiye'de toplam krediler içerisindeki paylarının yüzde 24'lere yükselmiş olmasıdır. $\mathrm{Bu}$ oran Amerika Birleşik Devletleri'nde yüzde 40'ın, Federal Almanya'da yüzde 35'in, Japonya'da yüzde 50'nin üstünde ve Güney Kore'de yüzde 50 civarında olduğu bilinmektedir. Buradan varılan sonuç, tartışılmasına gerek duyulmadan kabul edilmesi gereken bir Türkiye gerçeği olarak algılanabilir. Amaç yurdumuzda da bu oranın yüzde 50 sınırına doğru olmasıdır (Müftüoğlu, 2013: 280-281). Geçmiş dönemlere bakıldığında işletmelerin ölçek büyüklügüuyle finansman sorunları arasında ters yönlü bir korelasyon mevcuttur. İşletmelerin hacim ve kurumsallığı, kaynak yapılarının daha sağlam olması sonucunu doğurmaktadır. Dolayısıyla da ölçek büyüklüğünün artışı kaynak yaratma olanaklarının da artmasına yol açmaktadır (İSO, 2013: 54).

Tablo 2. Finansman Sorunu Yaşayan İşletmelerin Sorunlara Göre Dağılımı (\%)

\begin{tabular}{lcccc}
\hline & $\begin{array}{c}\text { Küçük } \\
\text { Ölçekli } \\
\text { Isşletmeler }\end{array}$ & $\begin{array}{c}\text { Orta } \\
\text { Ölçekli }\end{array}$ & $\begin{array}{c}\text { Büyük } \\
\text { Ölçekli }\end{array}$ & $\begin{array}{c}\text { Toplam } \\
\text { İşşletmeler }\end{array}$ \\
\hline $\begin{array}{l}\text { Kredi maliyeti } \\
\text { yüksekliği }\end{array}$ & 65,8 & 74,5 & 79,5 & 70,6 \\
\hline $\begin{array}{l}\text { İletme sermayesi } \\
\text { ihtiyacının hızla } \\
\text { artış1 }\end{array}$ & 52,5 & 57,5 & 74,4 & 57,1 \\
\hline $\begin{array}{l}\text { Özkaynak } \\
\text { yaratamamak }\end{array}$ & 47,5 & 39,6 & 28,2 & 42,2 \\
\hline Kredi bulamamak & 25,9 & 17,0 & 15,4 & 21,5 \\
\hline $\begin{array}{l}\text { Diğer } \\
\text { Vadeli kredilerin } \\
\text { yenilenmemesi }\end{array}$ & 18,4 & 18,9 & 10,3 & 17,5 \\
\hline $\begin{array}{l}\text { Teminat mektubu } \\
\text { limiti bulamamak }\end{array}$ & 3,8 & 12,3 & 7,7 & 7,3 \\
\hline $\begin{array}{l}\text { Toplam } \\
\text { Kaynak: İSO (2013) }\end{array}$ & 100,0 & 100,0 & 100,0 & 100,0 \\
\hline
\end{tabular}

Tablo 2'de gördüğümüz finansal sorunlara işletmelerin ölçekleri açısından bakmak gerekirse, kredi maliyetinin yüksek olması küçük, orta ve büyük işletmelerin üçü açısından da hemen hemen aynı oranlarda sorun teşkil etmektedir. İşletme sermayesi ihtiyacı küçük ve orta ölçekli işletmelerde \%52-\%57 aralığındayken, büyük ölçekli işletmeler için \%74'tür. Burada dikkat çekici diğer bir noktaysa özellikle küçük ölçekli işletmelerin özkaynak bulmakta yaşadıkları zorluktur.

Ülkemizdeki KOBI'lerin yaşadığı finansman sorunlarının temelinde 4 ana neden yatmaktadır (Aras, 2001):

(i) Ekonomik istikrarsızlık,

(ii) Bankacılık sisteminin yapısal sorunları,

(iii) Teşvik politikalarının yetersizliği,

(iv) KOBI'lerin kendi yapılarından kaynaklanan sorunlar.

KOBI'lerin finansmanla ilgili yaşadıkları sıkıntıları kredi temin etmede yaşanan sorunlar, özsermaye/işletme sermayesi yetersizliğinden kaynaklanan sorunlar, sermaye piyasasından fon elde etmede yaşanan sorunlar, finansal yönetimdeki yetersizliklerden kaynaklanan sorunlar ve alternatif finansman tekniklerinin yeterince kullanılmamasından kaynaklanan sorunlar oluşturmaktadır (Yörük, 2001).

\subsubsection{Kredi Temin Edilmesinde Karşılaşılan Sorunlar}

Türkiye'de KOBI'lerin kuruluş aşamasında ortaya çıkan finansman sorununun çözümü için öz kaynağın yetersiz olması halinde en sık başvurulan yol banka kredisidir. Yeterli sermaye birikimi olmayan küçük ve orta büyüklükteki işletmelerin finansman konusunda karşılaştıkları en önemli sorunlardan birisi de kredi ile finansman sağlamada karşılaştıkları sorunlardır. (Telim, 2002: 19).

Küçük ve orta büyüklükteki işletmeler, kredi yoluyla finansmanında en çok teminat gösterememe sorunuyla karşılaşmakta ve kısa vadeli finansman ihtiyaçlarını karşılamak için başvurdukları kredi kuruluşunun, kredinin verilebilmesi için istediği ipoteği veya kefaleti karşılamaya güçleri yetmemektedir. Bankaların sıfır riskle çalışma politikaları nedeniyle, bazen kredinin birkaç katı teminat talep edilmektedir. Büyük işletmeler aldıkları kredilere karşılık işletme varlıklarını teminat olarak gösterirken, küçük işletmeler ise genelde kişisel mal varlıklarını teminat olarak göstermektedirler. İflas durumunda ise küçük işletme sahibi tüm varlığını kaybetme tehlikesi ile karşı karşıya kalmaktadır. $\mathrm{Bu}$ durum küçük işletmelerin kredi yoluyla finansmanda çekimser davranmasına neden olmaktadır. (Karadal, 2002: 8).

\subsubsection{KOBI'lerin Özkaynak Yetersizliği}

Türkiye de kişi başına düşen milli gelir seviyesinin düşüklüğü, tasarruf eğiliminin az olmasına ve yatırımlara aktarılacak sermayenin oluşmamasına neden olmaktadır. $\mathrm{Bu}$ durum KOBI'lerin ihtiyaç duyduğu fon miktarını da kisitlamakta, yeni yatırım yapmak amacında olan girişimcileri, büyüme ve gelişen teknolojiye ayak uydurma çabasında olan küçük ve orta ölçekli sanayi kuruluşlarını finansman sorunu ile karşı karşıya bırakmaktadır. (Küçükçolak, 1998: 46) Türkiye ekonomisinin içinde bulunduğu makro ekonomik darboğazdan kaynaklandığını ve bunların kontrolünün de işletmelerin dışında kaldığııı ifade etmek gerekir. Kısa aralıklarla ortaya çıkan ve birbirini izleyen krizler, en çok gelişmekte olan ülkelerin reel 
ekonomileri üzerinde olumsuz yönde kalıcı etkiler bırakmaktadır. (Steven, 1986: 35)

Kuruluş aşamasında yeterli işletme sermayesi ile donatılmayan aynı zamanda yabanc1 kaynak bulmada zorlanan küçük ve orta boy işletmeler, pazarda ve genel ekonomik koşullardaki gelişmeler karşısında, işletme sermayesi ihtiyacının ağır sonuçlarına katlanmak zorunda kalmakta ve mevcut kapasitelerini artırma ve modernizasyon için gerekli atılımlarda bulunması doğrultusunda önemli sorunlar ortaya çıkmaktadır.

\subsubsection{Sermaye Piyasasindan Fon Elde Etmede Yaşanan Sorunlar}

Kredi temin etmede sorunlar yaşayan ve özkaynakları yetersiz olan KOBI'ler için sermaye piyasasından fon elde etme, önemli bir finansman alternatifi olarak karşımıza çıkmaktadır. KOBI'ler hisse senedi, tahvil, hisse senedi ile değiştirilebilir tahvil, kara iştirakli tahvil, katılma intifa senetleri, kar ve zarar ortakllğı belgesi, hisse senedi ile değiştirilebilir kar ve zarar ortaklığı belgesi ve finansman bonosu aracılı̆̆ıla sermaye piyasasından fon sağlayabilirler (Alptekin, 2007). Sermaye piyasası KOBI'ler için önemli bir finansman kaynağ 1 olmasına rağmen, daha önce de belirttiğimiz gibi KOBI'ler bu olanaktan çok fazla yararlanamamaktadırlar. Bu durumun başlıca nedenlerini şu şekilde sıralayabiliriz (Erkan vd., 2001):

(i) KOBI'lerin genellikle şahıs veya aile şirketleri oluşu ve yönetim hâkimiyetini kaybetme endişeleri

(ii) Halka açılmanın maliyeti

(iii) Şirketlerin çok küçük oluşları

(iv) KOBI'lerin organizasyon yapıları ve muhasebe sistemleri

(v) KOBI'lerin kayıt dışı kalmak istemeleri

KOBI yöneticilerinde geleneksel olarak 'yönetim bizde olsun, kimse karışmasın' anlayışı hâkim olmaktadır. KOBI'lerin halka açılırken katlanmak zorunda kaldıkları bazı giderler olduğu aşikârdır. Bunlar; bağımsız denetim ücretleri, reklam giderleri, hisse senedi basımı, ilan ve duyuru giderleri, satış komisyonu vs.. İşletmelerin küçük ölçekli olmalarından dolayı sermaye piyasalarına açılmanın çok fazla yarar getirmeyeceği düşüncesi hakim olmaktadır. KOBI'lerin sermaye piyasasının öngördüğü organizasyona ve muhasebe sistemlerine sahip olmamaları ve bazı işletmelerin kayıt dışı kalarak vergi ödememe eğilimleri küçük ve orta büyüklükteki işletmelerin sermaye piyasasına girmelerinin önündeki en önemli engeller olduğu söylenebilir.

\subsubsection{Finansal Yönetimdeki Yetersizliklerden Kaynaklanan Sorunlar}

Finans bilgilerinin yetersiz oluşu ve modern finansman tekniklerinin yeterince izlenememesi KOBI'lerin önemli mikro sorunları arasındadır (Müftüoğlu, 2013). Çoğu KOBI'nin ayrı bir finansman bölümünün olmayıșı, KOBI yöneticilerinin/sahiplerinin finansman konusunda yeterli olmayışları ve finansman alanında uzman kişileri çalıştırmamaları bu tür işletmelerin yaşadıkları sorunları derinleştirmektedir.

\subsubsection{Alternatif Finansman Tekniklerinin Yeterince Kullanılmaması}

KOBI'ler faaliyetlerini büyük oranda kendi kaynakları ile finanse etmekte, özkaynaktan sonra da bankalardan alınan kredileri kullanmaktadırlar. Aşağıdaki tablo incelendiğinde KOBI'lerin Eximbank'1, Avrupa Yatırım Bankası'nı, finans kurumların, leasingi ve factoringi finansman kaynağı olarak pek kullanmadıklarını görmekteyiz. KOBI'lerin ağırlıklı olarak özkaynak ve banka kredileri yoluyla finansman sağlamaları diğer alternatif finansman kaynaklarının avantajlarını kullanamamalarına neden olmaktadır (Kutlu ve Demirci, 2007:192-193).

\section{Metodoloji}

Çalışmanın bu kısmında araştırmaya ilişskin amaç, önem, ana kütle, örneklem, veri toplama yöntemleri, veri analiz yöntemleri ve bulgular yer almaktadır.

\subsection{Araştırmanın Amacı, Önemi ve Katkıları}

$\mathrm{Bu}$ çalışmanın amacı Diyarbakır ilinde faaliyet gösteren küçük ve orta büyüklükteki işletmelerin finansman ile ilgili sorunlarını ortaya çıarmak, bu sorunların irdelenmesinde dış kaynağın etkin rolünü ortaya koyarak çözüm önerileri geliştirmektir.

Ekonominin vazgeçilmez unsurları arasında yer alan KOBI'lerin sorunları arasında finansman, en önemli unsur olarak karşımıza çıkmaktadır. KOBI'ler yaşam mücadelesi verirken finansal sorunlarla sürekli uğraşmak durumunda kalmaktadırlar. KOBI'lerin temel özellikleri arasında yer alan sermaye yetersizliği, bu işletmelerin dış kaynak finansmanına yöneltmektedir. Dış kaynak finansman temini ve bu finansmanın maliyeti, finansmanın etkin kullanımı ve geri ödemesi beraberinde birçok sorunu da doğurmaktadır.

KOBI'lerin ayakta kalabilmeleri, pazar payını büyütebilmeleri ve başarılı olmaları finansal açıdan sorunların çözülmesiyle doğru orantılıdır. Bu bakımdan KOBI'lerin finansal açıdan güçlendirilmesi, finansal açıdan desteklenmesi ve finansal kültürlerinin artırılması yukarıda sayılan öğelerinde başarısına katkı sağlayacaktır.

\subsection{Araştırmanın Evren ve Örneklemi}

Araştırma evrenini, Diyarbakır ilinde faaliyette gösteren KOBI'ler oluşturmaktadır. Ocak 2018 Ticaret ve Sanayi Odası'ndan aldığımız verilere göre Diyarbakır'da 17652 KOBI mevcuttur. Yani Ana kütleyi 17652 küçük ve orta büyüklükteki işletmeler oluşturmaktadır. Hedef ana kütleye ulaşmanın içerdiği zorluklar nedeniyle; hedef daraltılacak ve random yöntemine göre ana kütle tanımlama yoluna gidilecektir. Ulaşılabilir ana kütleyi yaklaşık 386 KOBI'nin temsil edeceği düşünülmektedir. Belirlenen bu ulaşılabilir evrenin ana kütlemizi temsil yeteneğine sahip olduğu kanısı oluşmuştur. $\mathrm{Bu}$ kanıya, örneklem büyüklüguünün hesaplanmasında kullanılan şu formül üzerinden yapılan hesap sonucunda varılmıştır. 


\section{Örneklem Hacmi}

$\mathrm{n}=(\mathrm{N})(\mathrm{t} 2)(\mathrm{p} \times \mathrm{q}) \div(\mathrm{d} 2)(\mathrm{N}-1)+(\mathrm{t} 2)(\mathrm{p} \times \mathrm{q}) \operatorname{dir}$.

$\mathrm{Bu}$ formülde;

$\mathrm{N}$ : Hedef kitledeki birey sayıs

$\mathrm{n}$ : örnekleme alınacak birey sayısı

p: incelenen olayın gerçekleşme olasılığı

q: incelenen olayın gerçekleşmeme olasılığg

t: belirli bir anlamlılık düzeyinde, $\mathrm{t}$ tablosuna göre bulunan teorik değer

d: olayın görülüş sıklığına göre kabul edilen örnekleme hatasidir.

Buna göre;

$\mathrm{n}=17652 \times 3.8416 \times 0.25 \div 0.05 .0 .05 \times(17652-1)+3.8416 \times 0.25$

$\mathrm{n}=385.142 \ldots$

$\mathrm{n}=386$

\subsection{Verilerin Değerlendirilmesi}

Anket verilerinin toplanması yüz yüze görüşülerek yapılmıştır, bu yüzden anketlere verilen yanıtların samimi ve gerçeği yansıttığı varsayılarak hareket edilmiştir. Anket soruları işletmeye ait künye bölümü sorularından ve kredi teminine yönelik sorular 5'li likert ölçeğine göre sorulmuştur. Yanıtlar istatiksel programlar kullanılarak bilgisayar ortamında değerlendirmeye tabi tutulmuştur.

\subsection{Araştırmanın Hipotezleri}

Araştırmanın hipotezleri şu şekildedir:

$\mathrm{H}_{1}$ :Bankalardan yeterli kredinin alınamamas1 KOBI'lerde dıș kaynaklı finansal sorunların temelini oluşturur.

$\mathrm{H}_{2}$ : KOBI'lerin dış kaynak finansmanında vade, teminat, yeterlilik ve geri ödeme ön planda yer almaktadır.

\subsection{Araștırmanın Güvenirliliği}

Güvenirlilik katılımcıların test maddelerine verdikleri yanıtların tutarlılığı ile tanımlanmaktadır.

Çalışmada geliştirilen ölçeğin iç tutarlılık katsayısı (Cronbach Alpha) 0,767'dir. Bu katsayı ölçeğin güvenirlik düzeyinin yüksek olduğunu göstermektedir.

\subsection{Araştırma Bulgularının Değerlendirilmesi}

$\mathrm{Bu}$ bölümde araştırmaya katılan Diyarbakır ilinde ki KOBI'lerin finansal sorunların incelenmesinde dış kaynağın rolüne ilişkin anket sorularına vermiş olukları yanıtların istatiksel analizleri tablolar yardımıyla açıklanacaktır.

\subsubsection{Tanımlayıcı Analiz Sonuçları}

KOBI'lere ilişkin demografik veriler, frekans analizleri ile incelenmiştir. Elde edilen bulgular sırasıyla Tablo 3'de gösterilmektedir.
Tablo 3. Araştırmaya Katılan KOBI'ler ile İlgili Temel İstatistiki Bilgiler

\begin{tabular}{|c|c|c|c|}
\hline \multirow{2}{*}{ Değişken } & \multirow{2}{*}{ Özellik } & \multicolumn{2}{|c|}{$\mathrm{N}=386$} \\
\hline & & $\mathrm{F}$ & $\%$ \\
\hline \multirow{4}{*}{ Hukuki Durum } & - Adi Ortaklık & 124 & 32,1 \\
\hline & - Kollektif Şirket & 68 & 17,6 \\
\hline & - Limited Şirket & 166 & 43 \\
\hline & - Anonim Şirket & 28 & 7,3 \\
\hline \multirow{3}{*}{$\begin{array}{l}\text { İşletmelerin } \\
\text { Personel } \\
\text { Sayıları }\end{array}$} & $-1-9$ & 204 & 52,8 \\
\hline & $-10-49$ & 164 & 42,4 \\
\hline & $-50-250$ & 18 & 4,8 \\
\hline \multirow{4}{*}{$\begin{array}{l}\text { İşletmelerin } \\
\text { Faaliyet Süresi }\end{array}$} & $-1-5 \mathrm{y} 11$ & 66 & 17,1 \\
\hline & $-6-10 \mathrm{y} 11$ & 128 & 33,1 \\
\hline & $-11-20$ y1l & 164 & 42,5 \\
\hline & - 20 yıl ve üzeri & 28 & 7,3 \\
\hline \multirow{4}{*}{$\begin{array}{c}\text { İşletmelerin } \\
\text { Teşviklere Bakıs } \\
\text { Açısı }\end{array}$} & $\begin{array}{l}\text { - Teşvikler yeterli miktarda } \\
\text { verilmemektedir. }\end{array}$ & 124 & 32,1 \\
\hline & - Teşviklerde bürokrasi ve & 107 & 27,7 \\
\hline & $\begin{array}{l}\text { - Teşvikte sağlanan kredinin } \\
\text { malivetinin vüksekliği }\end{array}$ & 78 & 20,2 \\
\hline & $\begin{array}{l}\text { - Teşviklerin istenilen } \\
\text { zamanda alınamaması }\end{array}$ & 77 & 20 \\
\hline \multirow{4}{*}{$\begin{array}{c}\text { Anket Yapılan } \\
\text { İsletmelerin } \\
\text { Sermayeleri }\end{array}$} & $-100.000-400.000 \mathrm{TL}$ & 74 & 19,2 \\
\hline & - $401.000-700.000 \mathrm{TL}$ & 129 & 33,5 \\
\hline & - $701.000-1.000 .000 \mathrm{TL}$ & 138 & 35,6 \\
\hline & - 1.000 .000 TL üzeri & 45 & 11,7 \\
\hline \multirow{5}{*}{$\begin{array}{c}\text { İşletmelerin } \\
\text { Borç-Alacak } \\
\text { Düzeyleri }\end{array}$} & $\begin{array}{l}\text { - Alacak ve borç yapıs1 } \\
\text { dengededir }\end{array}$ & 74 & 19,2 \\
\hline & - Alacaklar borçlardan & 23 & 6 \\
\hline & $\begin{array}{l}\text { fazladır } \\
\text { - Borçlar alacaklardan } \\
\text { fazladır }\end{array}$ & 244 & 63,2 \\
\hline & - Borç bulunmamaktadır & 39 & 10,1 \\
\hline & - Yanit vermeyen & 6 & 1,5 \\
\hline \multirow{4}{*}{$\begin{array}{c}\text { Anketi } \\
\text { Yanıtlayanın } \\
\text { İşletmedeki } \\
\text { Konumu }\end{array}$} & - Sahip ya da ortak & 187 & 48,4 \\
\hline & - Müdür ya da yönetici & 105 & 27,2 \\
\hline & - Muhasebe ya da finans & 64 & 16,6 \\
\hline & $\begin{array}{l}\text { Sorumlusu } \\
\text { - İşletme personeli }\end{array}$ & 30 & 7,8 \\
\hline \multirow{3}{*}{$\begin{array}{c}\text { Anket Yapılan } \\
\text { İsletmelerin } \\
\text { Sermaye Temin } \\
\text { Kaynakları } \\
\end{array}$} & - Özkaynaklardan & 205 & 53,1 \\
\hline & - Yabanc1 Kaynaklardan & 181 & 46,9 \\
\hline & & & \\
\hline \multirow{5}{*}{$\begin{array}{l}\text { KOSGEB Kredi } \\
\text { Garanti Fonu } \\
\text { Gibi } \\
\text { Kurumlardan } \\
\text { Kredi Kullanım } \\
\text { Durumu } \\
\end{array}$} & - Kredi kullandım & 233 & 60,4 \\
\hline & - Kredi kullanmadım & 153 & 39,6 \\
\hline & & & \\
\hline & & & \\
\hline & & & \\
\hline
\end{tabular}

Tablo 3'deki bilgilerden KOBI'lerin özellikleri şöyle görülmektedir.

(i) KOBI'lerin \% 32,1 i adi ortaklık, \% 17,6'sı kolektif şirket, \% 43’ü limited şirket ve \% 7,3’ü anonim şirkettir.

(ii) İşletmelerin personel sayısına bakacak olursak ağırlığın \% 52,8 ile 1-9 kişi aralığında çalışanların (Mikro işletme) olduğunu görüyoruz.

(iii) İşletmelerin faaliyet sürelerinde 11-20 yıl aralığındaki KOBI'lerin \% 42,5 ile ağırlıkta olduğu görülmektedir.

(iv) İşletmelerin teşviklere bakış açısında \% 32,1 ile teşviklerin yeterli miktarda verilmediğini, \% 27,7 teşviklerde bürokrasi ve şartlar ağır olduğunu, \% 20,2 
teşvikte sağlanan kredinin maliyetinin yüksekliğini ve \% 20 teşviklerin istenilen zamanda alınamadığını dile getirmişlerdir.

(v) İşletme sermayelerinde ağırlığın \% 35,6 ile 701.0001.000.000 TL aralığında olduğu görülmektedir.

(vi) İşletmelerin borç-alacak düzeylerine vermiş oldukları yanıtlarda borçların alacaklardan fazla olduğunu \% 63,2 ile ağırlıkta olduğunu söyleyebiliriz.

(vii) Anketi yanıtlayanların işletmedeki konumu ise \% 48,4'ü sahip ya da ortak, \% 27,2'si müdür ya da yönetici, \% 16,6's1 muhasebe ya da finans sorumlusu ve $\% 7,8$ 'i işletme personelidir.

(viii) İșletmelerin sermaye teminlerinin $\% \quad 53,1$ ' $\mathrm{i}$ özkaynaklardan ve \% 46,9'u ise dış kaynaklardan (yabanc1 kaynaklardan) temin ettiklerini söyleyebiliriz.

(ix) KOSGEB kredi garanti fonu gibi kurumlardan kredi kullanım durumuna ilişkin KOBI'lerin verdikleri yanıtlarda \% 60,4'ü kredi kullandığını ve \% 39,6's1 ise kredi kullanmadıklarını söylemişlerdir.

\subsubsection{KOBI’lerin Dış Kaynak Finansmanına İlişkin Frekans Dağılımları ve Aritmetik Ortalamalar}

KOBI'lerin dış kaynak finansmanına ilişkin görüş, düşünce ve tutumlarının yer aldığı bu bölümde ilgili önermelere katılım derecelerinin gösterildiği istatistiksel ölçekte frekans dağılımları, aritmetik ortalamalar ve standart sapmalar sunulmuştur. D1ş kaynak finansmanına ilişkin frekans dağılımları ve aritmetik ortalamalar, aşağıdaki Tablo 4'de görülmektedir.

Tablo 4. KOBI'lerin Dış Kaynak Finansmanına Bakış Açılarının Ortalama ve Standart Sapma Değerleri

\begin{tabular}{|c|c|c|}
\hline Görüşler & $\begin{array}{c}\text { Katılım } \\
\text { Ortalamas1 }\end{array}$ & $\begin{array}{c}\text { Standart } \\
\text { Sapma } \\
\end{array}$ \\
\hline $\begin{array}{l}\text { 1. Dış kaynak ile finansmanın maliyeti } \\
\text { yüksektir. }\end{array}$ & 3,97 & 0,82 \\
\hline 2. Diş kaynakta vade sonu önemlidir. & 3,62 & 1,07 \\
\hline 3. Kredi faiz oranları yüksektir. & 4,39 & 0,67 \\
\hline $\begin{array}{l}\text { 4. Dış kaynağa işletmelerin olumlu } \\
\text { bakmayışları }\end{array}$ & 3,02 & 1,092 \\
\hline $\begin{array}{l}\text { 5. D1ş kaynağın istenilen miktarda } \\
\text { olmayışı }\end{array}$ & 3,95 & 0,80 \\
\hline $\begin{array}{l}\text { 6. Finans kuruluşlarını istediği } \\
\text { teminatların ağırlığ }\end{array}$ & 3,99 & 0,95 \\
\hline $\begin{array}{l}\text { 7. Bürokrasi ve koşullar dış kaynak } \\
\text { cazibesinin yitirilmesine neden } \\
\text { olmaktadır }\end{array}$ & 3,75 & 0,93 \\
\hline $\begin{array}{l}\text { 8. Banka kredileri dişında dış kaynak } \\
\text { bilgisine sahip olunmayışı }\end{array}$ & 4,14 & 1,076 \\
\hline $\begin{array}{l}\text { 9. KOBI'lere sermaye piyasası } \\
\text { araçlarından yararlanma imkânı } \\
\text { sunulmalıdır }\end{array}$ & 4,02 & 1,21 \\
\hline $\begin{array}{l}\text { 10. KOSGEB, kredi garanti fonu gibi } \\
\text { uygulamalar daha fazla KOBI'yi } \\
\text { kapsamalıdır }\end{array}$ & 3,98 & 1,18 \\
\hline $\begin{array}{l}\text { 11. Kamu bankalarında ki finansal } \\
\text { ürünlerden daha fazla } \\
\text { yararlanılmalıdır }\end{array}$ & 4,21 & 1,01 \\
\hline $\begin{array}{l}\text { 12. Diş kaynakda en önemli sorun geri } \\
\text { ödeme dönemlerinde yaşanan nakit } \\
\text { ihtiyacı }\end{array}$ & 3,94 & 1,13 \\
\hline
\end{tabular}

Tablo 4'de dış kaynak finansmanına ilişkin önermelerimize KOBI'lerin verdikleri yanitlarla katılım dereceleri ölçülmeye çalışılmıştır. En yüksek katılım oranının 4,39'luk bir dereceyle kredi faizlerinin yüksek olduğu önermesiyle gerçekleştiğini görmekteyiz. Bu oran KOBI'lerin sermaye teminini kredi yoluyla sağladıklarında sıkıntılar yarattığını, devletin bu konu hakkında adımlar atması gerekliliğini ortaya koymaktadır. Bu önermeyi 4,21 ile kamu bankalarında ki finansal ürünlerden daha fazla yararlanılması gerektiğini belirten önerme desteklemektedir. $\mathrm{Bu}$ önermelerin yanında katılım oranı yüksek olan diğer ifadelere bakacak olursak, 4,14 ortalama ile banka kredileri dışında dış kaynak bilgisine sahip olunmayışı ve 4,02 ortalama ile KOBI'lere sermaye piyasası araçlarından yararlanma imkânı sunulması gerekliliği önermelerdir.

KOBI'lerin en az katıldıkları önerme ise 3,02 ortalama ile dış kaynağa işletmelerin olumlu bakmayışları ifadesidir. Bu oran KOBI'lerin borçlanma yoluyla kaynak sağlamalarına sıcak bakmayışları daha çok öz sermayelerinde karşılama yanlısı olduklarının göstergesidir. Diğer düşük katılımlı önermeler ise, 3,62 ortalama ile dış kaynakda vade sonu önemli olduğunu ve 3,75 ortalama ile bürokrasi ve koşullar dış kaynak cazibesinin yitirilmesine neden olduğu önermelerdir.

\subsection{Araştırma Hipotez Testinin Yapılması}

$\mathrm{H}_{1}$. Bankalardan yeterli kredinin alınamaması KOBI'lerde dış kaynaklı finansal sorunların temelini oluşturmaktadır.

Hipotez analiz edildiğinde yapılan anketin KOBI'lerin faiz oranları, sermaye miktarı ile dış kaynak ilişkisi arasında anlamlı bir ilişki olduğu Tablo 5'de görülmektedir.

Tablo 5. KOBI'lerin Faiz Oranları, Sermaye Miktarı İle Dış Kaynak İlişkisi

\begin{tabular}{ccccc}
\hline Sermaye & N & $\begin{array}{c}\text { Sira } \\
\text { Ort }\end{array}$ & & \\
\hline & 74 & 39,23 & Chi-Square & 31,012 \\
$100.000-400.000 \mathrm{TL}$ & 129 & 46,35 & Df & 4 \\
$401.000-700.000 \mathrm{TL}$ & 138 & 59,23 & Asymp & 0,001 \\
$701.000-1.000 .000 \mathrm{TL}$ & 45 & 22,14 & Sig(P) & \\
1.000 .000 TL üzeri & & & & \\
\hline
\end{tabular}

Hipotez 0,05 anlamlılık düzeyinde test edilmiş Asym Sig(P) değeri $<0,05$ olduğundan hipotez kabul edilmiştir. Sıra düzeylerine baktığımızda 701.000-1.000.000 TL aralığında sermayeye sahip işletmelerinde kredilerde faiz oranlarının yüksekliğinin en fazla olduğu ortaya çıkmıştır.

$\mathrm{H}_{2}$.KOBI'lerin dış kaynakla finansmanda vade, teminat, yeterlilik ve geri ödeme ön planda yer almaktadır.

Hipotez analiz edildiğinde yapılan anketin KOBI'lerin borçalacak düzeyleri ile finans kuruluşlarının istediği teminatlar arasında anlamlı bir ilişki olduğu görülmektedir (Tablo 6).

Tablo 6. KOBI'lerin Borç-Alacak Düzeyleri İle Finans Kuruluşlarının İstediği Teminatlar Arasındaki İlișki

\begin{tabular}{lccc}
\hline İşletmelerin Borç Alacak Düzeyleri & $\mathrm{N}$ & $\begin{array}{c}\text { Sıra } \\
\text { ort }\end{array}$ & \\
\hline Alacak ve borç dengede bulunmaktadır & 74 & 24,12 & $\begin{array}{c}\text { Chi-Square } \\
41,024\end{array}$ \\
Alacaklar borçlardan fazladır & 23 & 8,02 & Df 5 \\
Borçlar alacaklardan fazladır & 244 & 74,18 & Asym \\
Borç bulunmamaktadır & 39 & 10,02 & Sig(p) \\
Yanıt vermeyen & 6 & 0,4 & 0,001 \\
\hline Toplam & 386 & & \\
\hline
\end{tabular}


$\mathrm{Bu}$ hipotez 0,05 anlamlılık düzeyi ve Asym sig(P) değeri $<0,05$ olduğu için kabul edilmiştir. Tablodan çıkan sonuçlara bakacak olursak borçları alacaklarından fazla olan işletmeler belirgin bir şekilde kendini göstermektedir.

\section{Sonuç ve Öneriler}

KOBI'lerimizin büyük bir kısmı birçok sorunla mücadele etmekte, istikrarlı gelişimden ve sağlıklı işleyişten uzak kalmaktadır. Söz konusu sorunların başında finansman sorunları gelmektedir. Finans dünyasındaki gelişmeleri yakından takip edememeleri, oto finansman olanaklarının kısıtlı olması, kredi alımlarında karşılaştıkları teminat sorunları, kredi hacimlerinin düşük ve kredi maliyetlerinin yüksek olması, sermaye piyasasına girememeleri ve diğer benzer sorunlar KOBI'lerin güçlü finansal yapılara sahip olmalarını engellemekte ve rekabet güçlerini azaltmaktadır. Küreselleşen dünyanın yeni ekonomisinde finansal sorunlarını aşamayan KOBI'lerin ulusal/uluslararası yoğun rekabet ortamında ayakta kalamayacakları gerçeğinden hareketle, ülkemiz KOBI'lerinin finansal durumları iyi analiz edilmeli, sorunlarına yapıcı, uzun vadeli, verimliliği artırmaya yönelik çözümler üretilmelidir.

Diyarbakır ilinde faaliyet gösteren 386 KOBI ile yaptığımız finansal sorunların incelemesinde diş kaynağın rolü konusunda yapılan anketler sonucunda şu bilgilere ulaşılmıştır:

Çalışmamızda KOBI'lerin dış kaynağın banka kredileriyle özdeş bir yapı gösterdiği ortaya konulmuştur. KOBI'ler yapıları itibariyle özkaynak yetersizliği içerisinde bulundukları için dış kaynağa ihtiyaç duymaktadırlar.

Anketi yanıtlayan işletmeler yabancı kaynakla finansmanın maliyetinin yüksekliğini ifade etmekle beraber kredi faiz oranlarının yüksekliğini de oldukça yüksek derecede bir katılım derecesi vererek kredi maliyeti ile faiz yüksekliğini eş değer bir şekilde değerlendirmişlerdir.

KOBI'ler banka kredileri dıșında dış kaynaklar konusunda yeterli bilgiye sahip değildirler. Bununla bağlantılı olarak KOBI'lerin sermaye piyasası araçlarından yaralanma imkânı sunulmasına yüksek derecede katılım göstermişlerdir. KOBI'lerin dıș kaynak finansmanında KOSGEB, kredi garanti fonu gibi kamusal teşviklerin yaygınlaştırılması ve kamu bankalarından daha fazla finansal ürün talepleri bulunmaktadır. Çalışmamızda vade ve kredilerin geri ödenmesinin de özellikle geri ödeme dönemlerinde işletmelerde nakit sıkıntısına neden olduğu ifade edilmiştir. Krediye ulaşmada bürokrasi ve uygulama koşullarının yabancı kaynak karşısında önemli engeller teşkil ettiği görülmektedir.

Çalışmamızda mal ve hizmet üretimi yapan KOBI'lerin özkaynak yetersizliğini dış kaynakla finanse ettikleri tespit edilmekle beraber, KOBI'lerin dış kaynakla finansman konusunda daha çok bilgiye ihtiyaç duydukları görülmüştür. Kamu bankaları, KOSGEB, ticaret ve sanayi odaları gibi kurumlarca bu kuruluşlara finansal ürünler ve dış kaynakların çeşitleri ve kullanım olanakları konusunda eğitim, seminer ve benzeri programlar düzenlenmelidir.

Anket uygulaması sonuçları göz önüne alındığında KOBI'lerin gelişerek, rekabet güçlerini artırmaları, daha fazla istihdam, katma değer ve verimlilik elde etmeleri için bazı politikaların geliștirilmesi, uygulanması gerekmektedir. Bunları aşağıda şekilde özetlemek mümkündür:

(i) KOBI'lerin finansal yönetimdeki yetersizliklerinin paralelinde KOBI'leri finansman hakkında bilgilendirecek ve modern finansman tekniklerinin kullanımı konusunda yönlendirecek eğitim programları düzenlenmelidir.

(ii) Dış kaynak kullanan işletme sayısı, işletme başına kullandırılan kredi miktarı, kredilerin vadesi, faiz oranı vb. kriterlere göre kredi imkanları yetersizdir. KOBI'lere verilen kredilerin şartları iyileştirilmelidir.

(iii) KOBI'lerin dış kaynak ile borçlanmalarının ağır teminat şartlarından dolayı büyük sıkıntılar çekmektedirler. Banka kredilerinde teminat problemlerinin giderilmesi için faaliyet gösteren kredi garanti kuruluşlarının sayıları artırılmalıdır.

(iv) KOBI'lerimiz özkaynak ve banka kredisi finansmanı harici finansman yöntemlerini çok fazla kullanmamaktalar. Bu gerçekten hareketle factoring, leasing gibi alternatif finansman yöntemlerinin daha yaygın kullanılmasına yönelik çalışmalar yapılmalidir.

(v) KOBI'lerin yaşadıkları dış kaynak ile sağlanan finansman sorunlarına yönelik KOSGEB tarafından internet ve diğer araçlarla yapılan bilgilendirilme yolları arttırılmalıdır.

(vi) KOSGEB' in KOBI'lere yönelik hizmet ağı ve hizmet kalitesi arttırılmalıdır.

(vii) KOBI'lere kuruluş aşamasından gelişim aşamasına kadar uzun ve orta vadeli kredi sağlayan bölgesel/yerel finans şirketleri kurulmalıdır.

(viii) Avrupa Yatırım Bankası'nın verdiği kredilerden ve Avrupa Birliği fonlarından yararlanmaları için küçük ve orta büyüklükteki işletmeler bu konularda yönlendirilmeli ve bilgilendirilmelidir.

(ix) KOBI Bankası oluşturulmalı ve geliştirilecek ürünler özellikle KOBI'lerin makina ve teknolojilerini geliştirmeye yönelik orta vadeli krediler olmalıdır.

\section{Kaynakça}

Akgemci, T. (2001). KOBI'lerin Temel Sorunlarl ve Sağlanan Destekler. Ankara: Kosgeb Yayını.

Alptekin, E. (2007). KOBI'ler Alternatif Finansman Kaynaklarının Farkında Mi?. AR-GE Bülten, İzmir: İzmir Ticaret Odasi.

Aras, G. (2001). KOBI'lerin Sermaye Piyasası Yoluyla Fon Sağlama Olanakları: Tezgahüstü Piyasalar ve Risk Sermayesi Finansman Modeli. İçinde: 1. Orta Anadolu Kongresi: KOBI'lerin Finansman ve Pazarlama Sorunları, Nevşehir.

Burlingham, B. (2007). Küçük Devler. İstanbul: Can Matbaacilik.

Cook, P., \& Nixson, F. (2000). Finance and small and medium-sized enterprise development. Manchester: Institute for Development Policy and Management, University of Manchester. (Accessed on 02/06/2018), http://www.gdrc.org/icm/micro/fin-sme.html

Çelik, A. \& Akgemci T. (1998). Girişimcilik Kültürü ve KOBI'ler, Nobel Yayın Dağıtım. 
Düşükcan, M., \& Sezgin, E.E. (2017). Küçük ve Orta Boy

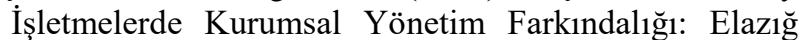
İlinde Bir Uygulama. Furat Üniversitesi Uluslararast Íktisadi ve İdari Bilimler Dergisi, 1(1), 153-182.

Erkan, M., \& Eleren, A. (2001). Küreselleşme Sürecinde KOBI'lerin Yeniden Yapılandırılmas1 ve Bir Model Önerisi. İçinde: 1. Orta Anadolu Kongresi: KOBI'lerin Finansman ve Pazarlama Sorunları, Nevşehir.

Gedik, S. (2011). KOBI'lerde Finansal Yönetim Tekniklerinin Uygulanması ve Malatya İlinde Bir Anket Çalışması. Yüksek Lisans Tezi. İstanbul: Marmara Üniversitesi.

Green, A. (2003). Credit Guarantee Schemes for Small Enterprises: An Effective Instrument to Promote Private Sector-Led Growth?. SME Technical Working Papers Series, UNIDO Working Paper No.10, s.1-88.

İSO (2013). Ekonomik Durum Tespiti Anket Çalışması Sonuçlarl 2013-1. (Erişim Tarihi: 10/10/2017), http://www.iso.org.tr/sites/1/upload/files/ekonomik_dur um_2013_1-16.pdf

Karadal, H. (2002). Küreselleşme Sürecinde KOBI Yöneticilerinin Profili Üzerine Bir Araştırma. İçinde: 21.Yüzyılda KOBI’ler: Sorunlar, Fırsatlar ve Çözüm Önerileri Sempozyumu, Doğu Akdeniz Üniversitesi, İşletme ve Ekonomi Fakültesi.

Kutlu, H. A., \& Demirci, N. S. (2007). KOBI'lerin Finansal Sorunları ve Çözüm Önerileri. İçinde: KOBI'ler ve Verimlilik Kongresi, İstanbul Kültür Üniversitesi.

Küçükçolak, R. A. (1998). KOBI’lerin Finansman Sorununun Sermaye Piyasası Yoluyla Çözümü. İstanbul: İMKB Yayını.

Müftüoğlu, M. T. (2013). Türkiye'de Küçük ve Orta Ölçekli Issletmeler, KOBI'ler Sorunlar-Öneriler. Ankara: Turhan Kitabevi.

Sarıaltın, H. (2011). Finansal Yönetim ve Finansal Yönetimin Ana Çerçevesi Semineri. (Erişim Tarihi: 02/06/2018),

www.sakaryasmmmo.org.tr/dosyalar/1323816181-7-22011.doc

Sarıarslan, H. (1994). Orta ve Küçük Ölçekli Işsletmelerin Finansman Sorunları. Ankara: TOBB Yayınları.

Steven, S. (1986). Small Business. New York: Crawn Publishers.

Taşçı, S. Z. (2017). Türkiye'deki KOBI'lerin 2010-2016 Yılları Arasında Banka Kredileri Kullanımının Diğer Finansman Yöntemleri İle Karşılaştırılması. Yüksek Lisans Tezi. İstanbul: İstanbul Kültür Üniversitesi.

Telim, C. (2002). KOBI Teşvik Belgesi Kapsamında Yapılan Yatırımlara Sağlanan Kredi Desteği. Yaklaşım Dergisi.

TOBB (2012). KOBİ Tanımı Değişti. (Erişim Tarihi: 02/06/2018),

https://www.tobb.org.tr/Sayfalar/Detay.php?rid=833\&ls $\mathrm{t}=$ DuyurularListesi
Vural, Ç. S. (2007). KOBI'lerin Sermaye Piyasasından Fon Temin Etmesi. Yüksek Lisans Tezi. İstanbul: Marmara Üniversitesi.

Yörük, N. (2001). KOBI'lerin Kredi Yoluyla Finansmanında Karşılaştıkları Sorunlar ve Tokat İlinde Bir Uygulama. İçinde: 1. Orta Anadolu Kongresi: KOBI'lerin Finansman ve Pazarlama Sorunları, Nevşehir. 